\title{
Clandestinidad y periferia. Usos del genero policial en la narrativa de Ricardo Piglia
}

\author{
Clandestinity and periphery. Uses of detective narrative in Ricardo Piglia's novels
}

\begin{abstract}
ANTONIO GARCÍA DEL RÍO
Universitat de València • angarde@alumni.uv.es

Máster en Estudios Hispánicos, actualmente trabaja en una tesis doctoral sobre representaciones de comunidades subalternas en la cultura contemporánea, centrada especialmente en la comunidad y la 'quinqui'.
\end{abstract}

RECIBIDO: 2 DE ENERO DE 2015

ACEPTADO: 3 DE JUNIO DE 2015

Resumen: El presente trabajo consiste en la observación de los usos de esquemas y situaciones del género policial en la narrativa de Ricardo Piglia (1940). Partimos en primer lugar del análisis del relato como esquema de personajes básicos del género; en segundo lugar, analizamos, a partir de una revisión teórica de la figura del detective y del género, cómo en sus novelas los medios de investigación utilizados por los detectives consisten en saberes, como la lectura y la escritura, que entran en conflicto con los del Estado; en tercer lugar, observamos cómo todos estos planteamientos se reflejan en las estructuras narrativas de las obras analizadas; finalmente, comprobamos cómo a través de los discursos estatales se esconde una visión que criminaliza y condena la sexualidad de los personajes, por lo que a través del pensamiento de Michel Foucault sobre las sociedades de vigilancia observaremos la vinculación establecida entre la sexualidad, la ley y los lugares de encierro y control.

Palabras Clave: Piglia, detective, investigación, crimen, ley, periodismo, sexualidad, ficción paranoica.

\begin{abstract}
This work involves the observation of the uses of schemes and situations of the detective genre in the narrative of Ricardo Piglia. We start first by the analysis of the tale as scheme of basic characters of the gender; Secondly, we analyze, from a theoretical review of the detective genre and how its novels research facilities used by detectives consist of knowledge, such as reading and writing, which conflict with State; Thirdly, we see how all these approaches are reflected in the narrative structures of the works analyzed; finally we check how through state vision criminalizing speeches hides and condemns sexuality of the characters, so through thought of Michel Foucault on surveillance firms observe the link established between sexuality, law and places of confinement and control.
\end{abstract}

Kay words: Piglia, detective, crime, law, paranoid fiction. 
Antonio García del Río. Clandestinidad y periferia...

\section{Introducción}

Este trabajo tiene como objetivo analizar el modo en que algunas narraciones de Ricardo Piglia hacen uso de elementos propios de la narrativa policial para escenificar las relaciones complejas y a veces contradictoras entre la ley, el crimen y la clandestinidad, trabajándolas como fuerzas enfrentadas dentro del marco de la ficción. La representación de dicho conflicto precisa materializarse a través de una serie de situaciones narrativas, protagonizadas por unos personajes que mediante sus acciones y debido a su caracterización permanecerán dentro o fuera de la legalidad, o en posiciones limítrofes que nos permiten visualizar la mutabilidad de la relación entre ley y crimen. Asimismo, la utilización de unos espacios determinados servirá para evidenciar, de un modo desplazado, las complejas relaciones entre la legalidad y la clandestinidad.

En un fragmento de Vigilar y castigar (1975) sobre el regicidio, Michel Foucault escribe: "En toda infracción, hay un crimen majestatis, y en el menor de los criminales un pequeño regicida en potencia" (Foucault, 2003: 59); o dicho de otra forma: cualquier infracción de la ley supone, en potencia, una impugnación completa del sistema legal y de su legitimidad social. En Plata quemada (1997), la escena final reelabora desde otras coordenadas esa idea: ante la imposibilidad de huir con él, el dinero robado en el asalto al banco es quemado por los atracadores, impidiendo de ese modo que pueda reintegrarse al circuito del consumo y del capital. El escándalo generado va más allá de sus consecuencias concretas: si hasta el siglo XVIII el rey era la representación del Estado, en la actualidad no hay más soberano que el dinero, la naturaleza del sistema capitalista. En esa escena emblemática, Piglia escenifica, a través de una persecución policial, un gesto de transgresión radical de la ley y de impugnación del símbolo mayor de nuestro sistema.

Algunas de las tramas de Piglia se sostienen sobre la exploración de las complejas vinculaciones entre los personajes, la ley, el crimen, la clandestinidad, el dinero y los símbolos del Estado; pero lejos de establecer una oposición entre ellas, las novelas exploran sus intersecciones. Por ejemplo, personajes que encarnan la legalidad -magistrados o policías- presentan actitudes corruptas que los sitúan fuera de la ley. Es más, algunos de ellos recurren a sujetos cercanos a la exclusión social para atribuirles su propia culpabilidad y, así, apuntalar su propia posición de poder en la sociedad.

En muchos casos, Piglia recurre a esquemas propios del género policial para articular narrativamente esta problematización de las relaciones entre la ley y el crimen. La investigación, como eje del argumento, constituye en algunos de sus relatos el espacio en que se va trazando un eje móvil que reubica a los personajes a un lado u otro de la ley. De este modo, la trabazón social y las relaciones entre ley, crimen y poder aparecen en sus ficciones como un enigma que la mecánica del policial intenta, a 
menudo de forma frustrada, resolver.

Así pues, las obras de Piglia, a través de las ficciones de investigación, utilizan de un modo crítico los modelos narrativos del género policial para escenificar las siguientes cuestiones: qué hay detrás de un crimen; qué motivaciones se esconden en su esclarecimiento; cuál es la necesidad de encontrar un individuo que pague las consecuencias sin que afecte al tejido social.

Bajo estas premisas, en nuestro trabajo analizaremos cómo en las novelas de Piglia se evidencian estos aspectos a través de los usos del policial. Como indica Sonia Mattalía, en La ley y el crimen (2008), el interés sobre la noción de uso del relato policial reside en observar: "de qué manera el género policial es usado por la narrativa argentina para representar el crimen y su relación con la ley" (Mattalía, 2008:12).

Para realizar nuestro análisis partiremos del relato breve "La loca y el relato del crimen" como muestra del esquema de personajes prototípico del género y para ello hemos consultado el estudio realizado por Sonia Mattalía (2008: 185-189). El relato fue vencedor de un concurso de la revista Siete Días en 1975 y editado en diversas compilaciones como algunas ediciones de Prisión perpetua (1988) o Cuentos morales (1995).

Respecto a las novelas analizadas, nos centraremos en las correspondientes a la segunda etapa de la producción de Piglia, desde Plata quemada hasta la actualidad, ya que en ellas el uso del policial es un factor estructural y explícito. Si seguimos el orden cronológico, en primer lugar, tenemos Plata quemada, vencedora del Premio Planeta de Novela en 1997, novela que relata la historia de un grupo de atracadores que tras el asalto a un banco huyen a Montevideo perseguidos por la policía.

En segundo lugar, trataremos Blanco Nocturno, publicada en el 2010, en la cual a partir del crimen de Tony Durán, portador del dinero de la herencia familiar de Luca Belladona, se revelará toda una trama de especulación y corrupción descubierta a partir de las investigaciones de Emilio Renzi y del comisario Croce.

En último lugar, analizaremos El camino de Ida, la última novela del autor, publicada en 2013. En ella, la extraña muerte de la profesora Ida Brown originará una trama de investigación en la cual se acabará comprobando la vinculación de su muerte con los asesinatos por parte del terrorista antisistema Thomas Munk.

En definitiva, comprobamos cómo a partir de los empleos del género en sus obras, Piglia reflexiona sobre las relaciones entre poder y sociedad, y cómo estas inciden en su narrativa, desde las 
Antonio García del Río. Clandestinidad y periferia...

formas narrativas hasta la configuración de las tramas.

\section{1. "La loca y el relato del crimen". Un esquema de personajes.}

Como punto de partida, tomaremos el relato breve "La loca y el relato del crimen", puesto que en él se concentran buena parte de las cuestiones que aparecerán desarrolladas en obras posteriores. En el relato, encontramos el asesinato de una prostituta y una investigación que tratará de esclarecer las responsabilidades del crimen. Para ello, nos encontramos ante un esquema básico de personajes de la narrativa policial: una víctima, un asesino, un testigo, un inculpado y un investigador ${ }^{1}$.

En primer lugar, encontramos al gordo Almada, el asesino, el centro violento y criminal del relato ${ }^{2}$. Este personaje no parece ser un individuo cualquiera, va a cometer un asesinato y le dice su nombre a la testigo Echavarne: “Ahí tenés. Yo soy Almada -dijo, y le alcanzó el billete. Comprate perfume” (Piglia, 1997: 90). Tal vez, su indiferencia y soberbia se deban a la locura y la poca credibilidad de la mujer o al hecho de ser consciente de su poder e inmunidad ante cualquier tipo de imputación, lo cual queda reflejado en las palabras del inculpado Antúnez: "Yo no he sido -dijo-. Ha sido el gordo Almada, pero a ese lo protegen de arriba" (Piglia, 1997: 93).

En segundo lugar, tenemos a la víctima, la prostituta Larry, de quien solo encontramos rastros por mediación del resto de personajes y de su premonitoria nota de despedida a Antúnez, su amante, escrita en rouge en un espejo; su efímero adiós es la descripción perfecta tanto de su paso y situación en el relato, como de la violencia que entraña la figura del asesino: "Vino él vino Almada vino a llevarme sabe todo lo nuestro vino al cabaret y es como un bicho una basura oh dios mío andate por favor [...] es una rata olvidame [...] porque él te va a matar” (Piglia, 1997: 92).

Asimismo, no debemos olvidar la condición de la víctima, una prostituta, es decir, un individuo marcado por la fragilidad que caracteriza su exclusión; en la investigación, ni a la policía ni a los medios de comunicación les interesa ir más allá de una resolución simple, que no se extienda a otra capa social más elevada, como la de Almada.

En tercer lugar, tenemos a Antúnez, amante de Larry e inculpado como ejecutor de su asesinato, el cual cerrará el triángulo sentimental del relato. Antúnez vive en el apartamento de Larry, después de que

\footnotetext{
${ }^{1}$ Como indica Sonia Mattalía: "el policial provee a la narrativa argentina una serie de figuras -la del criminal y del investigador, el enigma y su revelación, el crimen y la ley -con las cuales las ficciones literarias polemizan con las ficciones estatales" (Mattalía, 2008: 14).

${ }^{2}$ A través de la recreación de los pensamientos de Almada sobre la víctima, hallamos de primera mano su naturaleza violenta: "Poder humillarla una vez", pensó. "Quebrarla en dos para hacerla gemir y entregarse"” (Piglia, 1997: 89).
} 
Antonio García del Río. Clandestinidad y periferia...

esta le pidiera que se quedara para protegerla de su locura. El personaje es presentado como un hombre en proceso de decadencia, que sobrevive del dinero que la mujer lleva a la casa tras ejercer la prostitución. El hecho de no ser un elemento productivo para la sociedad y su poca relevancia dentro del marco social, lo convierten en el blanco fácil de las acusaciones: Antúnez, el chivo expiatorio ${ }^{3}$.

Así pues, la policía encuentra en él la solución al enigma; del mismo modo, el encargado del periódico no está dispuesto a ponerse en contra de la versión oficial, esto supondría la exposición a un riesgo, por dotar de credibilidad a individuos apartados del marco social, es decir, al testimonio de una indigente con claros síntomas de demencia, Echavarne, y a Antúnez, un supuesto proxeneta que comercia con el cuerpo de Larry.

En el relato, la testigo, Echavarne Angélica Inés, es un personaje fundamental, en palabras de Sonia Mattalía: "una loca pordiosera, una especie de Esfinge transmoderna, en cuyo delirio se localiza la verdad" (Mattalía, 2008: 187). En la figura de la loca se unen verdad y aislamiento: locura y mendicidad alejan a Echavarne de ser una pieza clave para la resolución del caso, la policía sabe que es testigo, la encontraron acunando el cadáver, pero el hermetismo de su discurso y su enfermedad la alejan de la credibilidad. Echavarne invade la comisaría con un lenguaje inconexo, que esconde la verdad del caso y la justicia que podría salvar a Antúnez, pero el discurso, hegemónico y oficial, aísla la verdad en favor de la complicidad de una resolución esperable.

Por lo tanto, nadie cree en ella y se convierte en objeto de burla desde el primer momento, tal y como hemos visto con Almada, hasta el instante en que su aparición debería ser crucial, ya que es la única que podría desvelar el enigma. De este modo, observamos, en la voz de Rinaldi, a qué reducen el testimonio de Echavarne: "Parece una parodia de Macbeth -susurró, erudito, Rinaldi-. Se acuerda, ¿no? El cuento contado por un loco que nada significa” (Piglia, 1997: 94).

Así pues, la esfinge Echavarne necesita un Edipo que resuelva el enigma, pero que no acabe cegado por sus ansias de conocimiento, un investigador que dé con las claves que nos introduzcan en el terreno de la verdad: ese hombre será Emilio Renzi, el personaje por excelencia en las ficciones de Piglia. Renzi, el crítico literario del diario El Mundo, en su papel como cronista de sucesos, topa de frente con dos versiones de la verdad: la de Echavarne y la del viejo Luna.

Como investigador será el único que atienda al testimonio de la loca, mientras que la policía y el periodista Rinaldi basan sus teorías en la culpabilidad de Antúnez. Asimismo, no podemos dejar de lado

${ }^{3}$ Podemos observar cómo nadie, excepto Renzi, otorga credibilidad a su versión, para ello tan solo debemos acudir a las palabras del viejo Luna: "Oíme, el tipo ese está cocinado, no tiene abogados, es un cafishio, la mató porque a la larga siempre terminan así las locas esas” (Piglia: 1997: 96). 
Antonio García del Río. Clandestinidad y periferia...

que Renzi es un lingüista, que "aplica la teoría de los operadores lógicos de Russell para analizar y reconstruir las estructuras repetitivas del discurso de la loca e interpretar sus desechos" (Mattalía, 2008: 186), por lo que accede a la verdad a través de la aplicación de un conocimiento que queda fuera de los métodos de investigación del Estado. Por lo tanto, Renzi descubre que el asesino fue el gordo Almada; esa declaración debe salir a la luz y acude al viejo Luna para exponer su investigación.

Su conversación establecerá el choque entre verdad y realidad que acabará determinando la solución final del relato. El viejo luna se muestra sorprendido con la investigación de Renzi y, consciente del peligro que conlleva sacarla a la luz, le dice a este: "Ya sé. Pero yo hace treinta años que estoy metido en este negocio y sé una cosa: no hay que buscarse problemas con la policía. Si ellos te dicen que lo mató la Virgen María, vos escribís que lo mató la Virgen María” (Piglia, 1997: 97).

Renzi no admite dejar de lado la verdad, ya que ese hecho implicaría, por un lado, la condena de un inocente y, por otro, la traición al acceso de la verdad a través de un procedimiento científico, del que él es especialista. De este modo, la solución reside en la propia ficción, en la utilización de una forma ajena a los discursos del Estado y al espacio público que es el periodismo (Mattalía, 2008: 187).

Por consiguiente, observamos cómo «La loca y el relato del crimen» prefigura un esquema de relaciones entre personajes y verdad que va más allá de los márgenes de la ficción, ya que nos introduce en la clandestinidad, no como forma de criminalidad, sino como búsqueda de un discurso que acceda al silencio del sistema, es decir, un discurso que ponga sobre la mesa el cuestionamiento del lenguaje, de las instituciones y del poder.

\section{La figura del investigador}

El caso de "La loca y el relato del crimen" no es un hecho aislado. Por el contrario, gran parte de la obra narrativa de Ricardo Piglia se sirve de las figuras y esquemas narrativos del policial clásico y de la novela negra para articular una reflexión lúcida y compleja sobre las relaciones entre la ley, la verdad, el Estado, el poder y, específicamente, sobre los lenguajes que atraviesan a todos ellos.

En ese sentido, podríamos indicar que Piglia hace un uso crítico de los tejidos del policial, fundamentalmente a través de las tramas de enigma y los personajes que llevan a cabo procesos de investigación. En los siguientes apartados, observaremos, por un lado, una caracterización teórica sobre el policial y el detective; por otro, cómo Piglia representa las investigaciones a través de unos saberes enfrentados con los del Estado. 
Antonio García del Río. Clandestinidad y periferia...

\subsection{Una aproximación teórica al género y a la figura del detective}

En El camino de Ida encontramos una reflexión significativa extraída del diario del personaje Thomas Munk: "Borrar las huellas es algo que los animales no saben hacer. Ésa es la mayor diferencia entre los hombres y las bestias” (Piglia, 2013: 195).

En estas palabras advertimos una de las claves por la que la figura del detective o investigador se convierte en la pieza fundamental dentro del género policial: reconstruir las huellas borradas por el criminal en la ejecución del delito. Tan solo a través del proceso de indagación de este personaje podrá completarse la resolución del conflicto en el que el crimen se convierte en el núcleo enigmático que habrá que revelar.

De este modo, encontramos dos términos esenciales que caracterizan a la figura del detective: investigación y verdad. Según Sonia Mattalía: “el relato policial trabaja con el eje del saber; es decir, su signo más evidente es la interrogación. Investigar, deducir, problematizar y responder son sus líneas centrales" (Mattalía, 2008: 14); por lo que, siguiendo a la autora, pensamos no solo en el género como una muestra del proceso de acceso a la verdad a través de la ficción, sino que también la literatura se constituye como: "espacio privilegiado de la busca de la verdad" (Mattalía, 2008: 14).

Si consideramos que el género trabaja sobre la interrogación, esta se establecerá sobre un punto concreto que la historia deja en suspenso, es decir, el crimen, y que su resolución será el objetivo

principal. Slavoj Žižek indica que la estructura del relato policial es circular, por lo que el inicio de la historia correspondería con dicha interrogación construida sobre: "un vacío, un blanco de lo no explicado o, más exactamente, de lo no narrado [...] El relato rodea este vacío, es puesto en marcha por el intento del detective a reconstruir la falta narrativa interpretando los indicios" (Žižek, 2000: 103).

Así pues, el detective, además de personaje dentro del esquema narrativo, se convertirá en el articulador que cohesionará los vacíos del relato y romperá el hiato generado por el crimen con el fin de sacar la verdad a la luz y poder dar forma a la historia. Como indica Piglia al reflexionar sobre la relación entre psicoanálisis y literatura a través del género policial, el detective: "Va a decir la verdad, va a descubrir la verdad que es visible pero que nadie ha visto, y la va a denunciar” (Piglia, 2000: 67).

Si situamos la figura del detective en el eje cronológico que abarca desde el surgimiento del género como relato de enigma con "Los crímenes de la rue Morgue" (1841) de Edgar Allan Poe hasta su desarrollo en la novela negra con representantes como Dashiell Hammett o Raymond Chandler, observamos cómo se ha producido un proceso evolutivo en la naturaleza del personaje, el cual 
responderá a la evolución de las dinámicas sociales y económicas ${ }^{4}$.

Por lo tanto, nos encontramos ante dos tipologías: el detective clásico y el detective duro de la novela negra. Žižek establece su diferenciación a partir de dos hechos: el grado de compromiso e implicación del investigador respecto al crimen y su actitud frente a la recompensa monetaria. Por un lado, en lo referente a la implicación, el detective clásico: "se mantiene en una posición excéntrica; está excluido de los intercambios que se producen en el grupo de sospechosos constituidos por el cadáver"; mientras que el detective duro: "está involucrado desde el principio, atrapado en el circuito: este compromiso define su posición subjetiva” (Žižek, 2000: 106-107).

Por otro lado, en cuanto a la compensación por sus servicios, Žižek indica que “el detective clásico acepta con notorio placer el pago por los servicios que ha prestado, mientras que el detective duro, como regla, desdeña el dinero y soluciona sus casos con el compromiso personal de alguien que se entrega a una misión ética". No obstante, matiza la posición del detective clásico indicando que: "el pago le permite no mezclarse en el circuito libidinal de la deuda (simbólica) y su rescate (Žižek, 2000: 106).

Sin embargo, en Piglia observamos unas consideraciones diferentes respecto a las formuladas por Žižek con relación a los tipos de investigadores. La caracterización de Piglia también se fundamentará en la contraposición de la figura del detective desde la novela de enigma hasta la novela negra, y para ello usará los mismos criterios de Žižek: la implicación del detective y la compensación del servicio a través del dinero, pero el resultado diferirá de las consideraciones indicadas anteriormente.

Por un lado, respecto al grado de implicación en los sucesos, la postura de Piglia no se distanciará mucho respecto a la de Žižek; mientras que de la novela de enigma o clásica nos indica que: "Las reglas del policial clásico se afirman sobre todo en el fetiche de la inteligencia pura [...] la figura del investigador como el razonador puro, como el gran racionalista que defiende la ley y descifra enigmas" (Piglia, 2001: 60); por lo que nos encontramos ante el planteamiento de un duelo de inteligencias en el que: "todo se resuelve a partir de una secuencia lógica de presupuestos, hipótesis, deducciones, con el detective quieto y analítico" (Piglia, 2001: 60).

Respecto a la evolución del detective en el género negro, Piglia nos indica que: investigador se lanza, ciegamente, al encuentro de los hechos, se deja llevar por los acontecimientos y su investigación produce fatalmente nuevos crímenes, una cadena de acontecimientos cuyo efecto es el descubrimiento, el desciframiento" (Piglia, 2001; 60).

${ }^{4}$ En el libro Historia de la novela policiaca (1967) de Fereydoun Hoveyda encontramos recogida la evolución de la novela policial desde sus posibles fuentes hasta la transformación del género a la serie negra. 
Antonio García del Río. Clandestinidad y periferia...

Mientras el género clásico plantea al detective bajo el prototipo de Dupin, en la novela negra: “el investigador viene directamente de lo real, es una figura histórica que duplica y niega al detective como científico de la vida cotidiana" (Piglia, 2001: 61).

El punto de divergencia respecto a la postura de Žižek es, fundamentalmente, el dinero. Para Piglia la novela negra se caracteriza por el papel, prácticamente estructural, que juega el dinero en el género ${ }^{5}$. Así pues, nos encontramos ante dos posturas diversas que giran en torno a un mismo eje: el dinero. Mientras Žižek sostiene que el detective clásico consigue el distanciamiento emocional respecto al caso a través de la recompensa monetaria, Piglia nos indica que el detective clásico actúa bajo la premisa de la lucha de inteligencias y la resolución del enigma a través de un conocimiento científico y ordenado de la realidad.

En cambio, respecto al género negro, las motivaciones criminales siempre tienen un trasfondo económico y la figura del detective es la de un profesional que no llevará a cabo sus funciones sin un pacto económico previo que garantice su remuneración. La condición inicial, y final, de la novela negra parte del dinero, por lo que encontramos en las palabras de Piglia una de las claves de su lectura:

El único enigma que proponen-y nunca resuelven- las novelas de la serie negra es el de las relaciones capitalistas: el dinero que legisla la moral y sostiene la ley es la única razón de estos relatos donde todo se paga. [...] yo diría que son novelas capitalistas [...] deben ser leídas como síntomas (Piglia, 2001: 63).

De esta manera, en gran parte de las novelas de Piglia, a través del uso de ciertos modelos del policial, quedará planteada una red de vinculaciones entre la ley y el dinero que el detective, a través de la ficción, tratará de evidenciar. Bajo un marco de relaciones capitalistas, la ley basará su discurso y sus actuaciones en una defensa económica de sus intereses, por lo que el desenmascaramiento de la verdad supondrá una interferencia en sus verdaderas motivaciones.

Tal y como hemos indicado, el acceso a la verdad por parte del detective lo convertirá en un sujeto conflictivo para la ley; su figura pondrá en peligro los cimientos sobre los que el Estado ha establecido un modelo de relaciones que determinará a ciertos individuos como peligrosos. Por lo tanto, en muchos casos, el detective será relegado a la clandestinidad; ya no será una ayuda, sino que será la amenaza.

\footnotetext{
${ }^{5}$ Como indica Piglia al respecto: “el que representa la ley solo está motivado por el interés, el detective es un profesional, alguien que hace su trabajo y recibe un sueldo (mientras que en la novela de intriga el detective es generalmente un aficionado que se ofrece «desinteresadamente» a descifrar el enigma); en segundo lugar, el crimen, el delito, está siempre sostenido por el dinero [...] a diferencia, otra vez, de la novela de enigma, donde en general las relaciones materiales aparecen sublimadas: los crímenes son «gratuitos», justamente porque la gratuidad del móvil fortalece la complejidad del enigma)" (Piglia, 2001: 61- 62).
} 
Antonio García del Río. Clandestinidad y periferia...

En las obras de Piglia no podemos caracterizar a la figura del detective bajo una tipología homogénea, sino que se establece una dialéctica de personajes y de técnicas de investigación que tomarán rasgos tanto del detective clásico de signo racionalista como del correspondiente al género negro. Esta heterogeneidad servirá a un fin común: evidenciar el funcionamiento y la cara oculta del poder a través de unos saberes que problematizan con el pretendido discurso normativo y hegemónico del estado.

\subsection{Periodismo y lectura, saberes opuestos a la ley}

Los procesos de investigación, en las obras de Piglia, serán el fundamento narrativo sobre el que tendrá lugar la construcción de las ficciones. Como muestra de ello, debemos establecer como punto de partida la figura de Emilio Renzi, el personaje investigador por excelencia de Piglia.

Renzi, más allá de su configuración como personaje, se convierte en la representación de una visión concreta de la realidad o lo que podríamos llamar un filtro de la realidad a través de la lectura. Tal y como indica Piglia sobre su personaje: «es un efecto de estilo, un tono, digamos, un modo de narrar [...] En el fondo solo le interesa la literatura, vive y mira todo desde la literatura» (Piglia, 2001: 93).

Dentro de las ficciones, suele representar la figura del periodista especializado en crítica literaria, envuelto en la investigación de un caso que tratará de resolver a partir de diversas técnicas y medios ${ }^{6}$. Renzi es, pues, un personaje vinculado a la lectura y la escritura, dos de los medios empleados en sus labores de investigación.

Si pensamos en la figura de Renzi desde su posición como reportero, observamos su confrontación con los representantes de la ley y la importancia del periodismo como modo de representación de los procesos de investigación y escritura sobre los $\operatorname{casos}^{7}$.

\footnotetext{
${ }^{6}$ Renzi, en "La loca y el relato del crimen", Plata Quemada y Blanco Nocturno es uno de los corresponsales del periódico El Mundo, mientras que en El camino de Ida, es un profesor visitante a cargo de un seminario sobre W.H.Hudson

${ }^{7}$ Sobre el lugar del periodismo dentro del género policial, Ricardo Piglia indica que: "En el medio, entre la novela de enigma y la novela dura, está el relato periodístico, la página de crímenes, los hechos reales. Auden decía que el género policial había venido a compensar las deficiencias del género narrativo no ficcional (la noticia policial) que fundaba el conocimiento de la realidad en la pura narración de los hechos. Poe [...] separa de los hechos reales con el álgebra pura de la forma analítica y abre paso a la narración como reconstrucción y deducción [...] La pura ficción, digamos, que trabaja la realidad como huella, como rastro, la sinécodque criminal [...] Poe está en el medio, entre la pura deducción y el reino puro de los facts, de la non-fiction" (Piglia, 2001: 60-61).
} 
Antonio García del Río. Clandestinidad y periferia...

El papel del periodismo, dentro del marco de la ficción, adquiere un rol ambivalente en su relación con el Estado, es decir, con la ley. Por un lado, la ley tratará de manejar la opinión pública y esconder la verdad a través de los medios de comunicación. Por otro lado, el investigador como periodista y los medios que emplea para el acceso a la verdad, supondrán un problema para el Estado, ya que en el momento en el que se rechaza el discurso oficial, el investigador entra en una relación de conflictividad con la ley, convirtiéndose, de este modo, en parte de la clandestinidad.

Si acudimos a Blanco Nocturno, encontramos una de las formas de tensión entre Estado e investigación a través de las actitudes de los representantes de la ley hacia el periodismo. En la novela, advertimos la ambivalencia del periodismo como herramienta de manipulación por parte de Cueto y como actividad amenazadora por medio de Renzi.

El fiscal Cueto, en su enfrentamiento con el comisario Croce, hace uso del periodismo para difamar al comisario y muestra, en todo momento, su concepción utilitaria de los medios de comunicación $^{8}$. Debemos destacar que en el momento en que se alude a la manipulación del periodismo por parte de la ley se introduce la figura de Renzi como punto de ruptura del uso demagogo del medio. Su relación con el fiscal será problemática desde el primer momento, puesto que Cueto ve en el reportero el factor desestabilizador de sus planes especulativos relacionados con el crimen.

Renzi, con su investigación y filiación con el comisario Croce, revela el conflicto investigación-ley. Sus capacidades y medios de acceso a la verdad incomodan al fiscal y su relación con la ley situará sus acciones en la clandestinidad. Cuando el comisario Croce niega la versión del crimen sexual, apoyada por el fiscal, debemos observar qué tratamiento recibe Renzi por parte de este: "El asunto está resuelto, no hace falta seguir dándole vueltas. Mejor se va, amigo, ya no tiene nada que hacer acá [...] no me gusta lo que escribe [...] no te metas donde no te llaman” (Piglia, 2010, 167).

En Blanco nocturno, la figura de Renzi adquiere dos funciones fundamentales; por un lado, es el reconstructor tanto de la historia familiar de los Belladona, como de la historia del pueblo 9 . Por otro lado, las indagaciones de Renzi nos introducen las voces de los personajes que se han visto marginados por

${ }^{8}$ Una muestra de este hecho lo encontramos en las siguientes muestras: "El fiscal Cueto le estaba armando campañas de prensa desde el momento en que se hizo cargo de la fiscalía" (Piglia, 2010: 107) y "sólo quería sacarlo del medio y sabía que la clave era recurrir al periodismo para desacreditarlo" (Piglia, 2010: 108). Asimismo, el utilitarismo del periodismo por parte de Cueto se evidencia a través de las palabras que dirige a Renzi: “¿Qué dicen las conciencias alquiladas de la patria?” (Piglia, 2010: 131)

${ }^{9}$ A través de la inserción de fragmentos en cursiva a final de cada capítulo se reproducen los encuentros entre Renzi y Sofía Belladona, que nos permitirán comprender tanto la historia de la familia, como la del pueblo y ciertos aspectos del crimen. 
parte de la ley: el comisario Croce y Luca Belladona. Tal vez, el hecho más peligroso para el fiscal sea que el periodismo favorezca las voces de todo aquello que ha pretendido ocultar.

La ambivalencia del periodismo en cuanto al papel del investigador también queda reflejada a través del personaje del viejo Luna. Como hemos comentado, en «La loca y el relato del crimen», el viejo, como encargado del periódico, nos muestra la experiencia en la relación entre la ley y el periodismo. En sus palabras se materializan las redes invisibles que traza el Estado con relación a la sociedad y la $\operatorname{verdad}^{10}$.

Como en el relato, Luna condiciona a Renzi en su propósito de mostrar la verdad, es decir, en la escritura como representación de lo no visible. El viejo no quiere perjudicar su negocio por enfrentarse a la ley, es consciente de los efectos del poder y sus estratagemas: "Son malevos, querido, pero en ellos la dimensión del mal es mínima comparada con quienes dan las órdenes [...] así que no te hagas el loco y escribí lo que ellos te digan” (Piglia, 2010: 140).

Por lo tanto, nos encontramos ante un conflicto en el que se enfrentan dos tipos de discursos, dos ópticas diversas respecto al acceso a la verdad: el discurso del poder y el trabajo crítico del detective. Como indica Nuria Girona:

Cualquier régimen verdad implica privilegiar ciertos tipos de discursos, sancionar ciertas formas de distinguir afirmaciones falsas de las verdaderas, aprobar ciertas técnicas de acceso a la verdad, conceder un cierto estatus a aquellos que las empleen competentemente [...] Estamos sometidos a la verdad en el sentido en que la verdad hace ley, elabora el discurso verdadero que, al menos, en parte, decide, transmite, empuja efectos de poder (Girona, 1995: 146).

Así pues, la ley construirá una versión determinada de los hechos a través de un discurso establecido y defendido por unas instituciones oficiales, que entrarán en conflicto con el detective y sus medios de acceso a la verdad. Por ello, en muchos casos, el detective será relegado a la clandestinidad por poner en peligro el discurso del poder.

Como indica Piglia sobre los detectives prototípicos del género: “Dupin, Sherlock Holmes, Marlowe, el detective privado está ahí para hacer ver que la ley en su lugar institucional, la policía, funciona mal” (Piglia, 2000: 67). El mal funcionamiento de la ley y su incapacidad para resolver los casos

\footnotetext{
${ }^{10}$ En Blanco nocturno observamos cuál es la descripción que Luna realiza de los comisarios de policía: “Ellos son nuestros nuevos héroes, querido, [...] Son los especialistas del mal, los encargados de que los idiotas duerman tranquilos [...] Se mueven entre la ley y el crimen [...] Son los guardianes de la seguridad y la sociedad les delega la función de ocuparse de lo que nadie quiere ver" (Piglia, 2010: 139).
} 
Antonio García del Río. Clandestinidad y periferia...

se evidenciará a través de la contraposición de las técnicas usadas por el detective, en nuestro caso, la lectura y la escritura ${ }^{11}$.

En las novelas de Piglia, encontramos una muestra de la impotencia en la resolución de los casos por parte de la policía. En El camino de Ida, el periódico The New York Times recibe diversas cartas anónimas, procedentes del terrorista Thomas Munk, en las que se incluye una alusión literaria, prácticamente indescifrable, a los ojos de los no especialistas, a un personaje del Finnegans Wake de James Joyce.

Ante estas cartas, el jefe de Investigaciones Especiales del FBI John Menéndez, a pesar del despliegue de medios tecnológicos, muestra su incapacidad para descifrar los rastros que el asesino deja en sus comunicaciones: "Era imposible adivinar lo que quería decir esa estupidez erudita" (Piglia, 2013: 148). Ante esto, es necesaria la intervención de un experto en literatura que pueda estrechar el cerco en cuanto al perfil del criminal; sin embargo, la policía tan solo consigue dar con el asesino no por sus propios medios, sino a través de la delación del hermano del terrorista.

En este planteamiento, la ley es incapaz de descifrar la verdad a través de un saber que le es ajeno, no es una lectora competente y tan solo puede resolver el caso a través de un hecho fortuito como la delación o la inculpación, voluntaria o involuntaria, de individuos inocentes, como Antúnez en "La loca y el relato del crimen".

Si pensamos en la lectura como forma de acceso a la verdad, debemos destacar que en "Los crímenes de la rue Morgue”, la resolución del enigma por Dupin se realiza, fundamentalmente, a través de la lectura de artículos periodísticos que reseñan el asesinato de dos mujeres e insertan las voces de diversos testigos que muestran su particular percepción de lo sucedido en el lugar del crimen. Como indica Piglia: "la lectura es la capacidad que usa para descifrar los casos [...] Los periódicos son el escenario cotidiano del crimen. Y el género es su doble: nace allí y nace para leer de otro modo y así cortar el flujo de lo que no se deja descifrar" (Piglia, 2005: 84).

En las obras de Piglia, la lectura es uno de los principales medios de investigación, un saber antagónico a los discursos del Estado. De este modo, podemos trazar un paralelismo basado en la figura

\footnotetext{
${ }^{11}$ Si miramos atrás, encontramos en «Los crímenes de la rue Morgue» la representación de la imposibilidad del éxito en la investigación por parte de la policía y la capacidad de Dupin en la resolución a través de su método analítico; de este modo, consideramos importante extraer una cita de las palabras de Dupin sobre este hecho: «La policía parisiense [...] es muy astuta pero nada más. No procede con método, salvo el del momento [...] Los resultados obtenidos son con frecuencia sorprendentes, pero en su mayoría se logran por simple diligencia y actividad» (Poe, 2004: 414).
} 
de lector competente, entre Dupin y la vecina rusa de Renzi, Nina Andropova, en el El camino de Ida. El modelo de detective clásico caracterizado por Dupin, el cual a través de la lectura de noticias y sin salir de casa consigue resolver el caso, muestra similitudes con la figura de Nina. Es una catedrática jubilada de Literatura en el Departamento de Lenguas Eslavas especializada en Tolstói, conoce los entresijos de la vida académica y de la historia.

Respecto a la muerte de Ida, Renzi indica que su vecina fue la primera en descifrar lo sucedido a través de la lectura de la prensa: "Sólo algunas notas aisladas en los periódicos permitían imaginar una sucesión de incidentes entre los que podía incluirse también la muerte de Ida" (Piglia, 2013: 108). Mientras el FBI trata de descifrar los mensajes enviados por el terrorista Thomas Munk, ella, mediante su conocimiento de la historia y comparándolo con los revolucionarios rusos, deduce los rasgos que caracterizan al terrorista: el aislamiento y la soledad.

En la misma novela, observamos el papel nuclear de la lectura como acceso a la verdad y como punto de cruce entre la realidad y la ficción. Tras el descubrimiento de la identidad del terrorista, Renzi encuentra el libro The Secret Agent, de Joseph Conrad, que Ida le dejó justo en el momento de su última despedida. El hallazgo del libro y las marcas que Ida realizó en él, constituyen la anagnórisis de Renzi. A través de la inserción de la imagen de una página del libro que Ida trabajó, observamos cómo Renzi indica: «ella tejía, con sus señas, un relato secreto, en voz baja, pequeños indicios [...] Los fragmentos desarticulados que Ida iba enlazando en la novela formaban un tejido que dejaban ver- a trasluz- la figura de Munk» (Piglia, 2013: 226-229).

Los fragmentos señalados por Ida ponen sobre la mesa la ideología y metodología que seguía Munk en sus crímenes, por lo que observamos la función de la lectura como medio de comprensión de una realidad difícilmente inteligible: "No era la realidad la que permitía comprender una novela, era una novela la que daba a entender la realidad que durante años había sido incomprensible" (Piglia, 2013: $231)^{12}$.

En definitiva, los investigadores, ajenos a la ley, emplean unos determinados saberes que están fuera del alcance de los que poseen las instituciones estatales, como la policía. Este hecho es representado a través de un factor recurrente en el género policial, la incapacidad de Estado para desvelar el enigma de lo social.

\footnotetext{
${ }^{12}$ Asimismo, se introduce una reflexión sobre el cruce entre la realidad y la ficción a partir de Thomas Munk, como lector alienado por sus propias lecturas: «Un lector de novelas que busca el sentido en la literatura y la realiza en su propia vida. Bovarismo era el término para designar el poder que tiene el hombre para concebirse otro del que es y crearse una personalidad» (Piglia 2013: 232).
} 
Antonio García del Río. Clandestinidad y periferia...

Si en "La loca y el relato del crimen” la deducción se establece a través de una técnica lingüística, en El camino de Ida la cultura literaria erudita es la clave de lectura desde la cual se puede interpretar el desorden de lo real. Así pues, dicha interpretación se realiza a través de la lectura de la prensa, por lo que observamos cómo el periodismo es el soporte que permitirá a los investigadores llevar a cabo sus funciones.

\subsection{Escritura, detectives y paranoia}

En el fragmento XI de "Tesis sobre el cuento", Piglia plantea lo siguiente sobre el relato: "Reproduce la busca siempre renovada de una experiencia única que nos permita ver, bajo la superficie opaca de la vida, una verdad secreta" (Piglia, 2000: 111). Esa verdad secreta es planteada bajo la forma del enigma, el cual Piglia considerará, en su segunda tesis, como el relato secreto que se inserta dentro del cuento, por lo que: "La estrategia del relato está puesta al servicio de esa narración cifrada" (Piglia, 2000: 108).

En el apartado anterior, hemos señalado que ante la incapacidad de la policía en el uso de unos saberes que no se hallan en su dominio, los procesos de investigación se multiplican debido a las diferentes voces que subyacen de las novelas; por tanto, cada personaje, por medio de su interpretación y de un saber determinado, planteará las diversas formas de descifrar la verdad oculta bajo lo aparente.

A través de la diversidad de personajes que investigan los casos, se produce una dialéctica entre técnicas y modos de investigación: cada novela muestra, precisamente, el conflicto entre diferentes modos de afrontar, leer y tratar de descifrar los enigmas, mediante esa pluralidad de las figuras investigadoras. En El camino de Ida, por ejemplo, dicho diálogo detectivesco confluye en la figura de Renzi; si pensamos en el modelo comunicativo: emisor-mensaje-receptor, Renzi se presentaría como el receptor de los mensajes de dos personajes que representan los dos modelos canónicos de detective que el propio Piglia distingue.

Por un lado, encontraríamos al que podríamos llamar emisor 1, la vecina rusa, Nina Andropova. Como hemos visto, a través de su figura queda planteada su posición como el tipo de detective clásico: por un lado, analiza la información a través de su conocimiento y la lectura de periódicos; y por otro, no recibe ningún tipo de remuneración. Se trata, pues, de una suerte de Dupin que ofrece su saber como ayuda a Renzi para descifrar el caso de Ida Brown. Por otro lado, tenemos la figura de Ralph Parker, el emisor 2, quien según Renzi: “era un típico expolicía norteamericano, despiadado, cínico y patriótico" (Piglia, 2013: 119). Parker podría representar el modelo de detective que Piglia describe 
Antonio García del Río. Clandestinidad y periferia...

para la serie negra; mientras que con Nina observamos una relación basada en la inteligencia y en la ayuda en la resolución del enigma; con Parker, desde el momento en que Renzi precisa de sus servicios, su relación deberá entenderse bajo un marco capitalista, se establece un pacto de remuneración, por lo que como profesional actúa solo movido por el dinero.

El mensaje que Parker transmite a Renzi es de tipo pragmático, fruto de la experiencia en su relación con la policía. Su labor se materializará convirtiéndose en el canal que mostrará las sospechas y los movimientos del FBI en el caso, obtendrá información privilegiada sobre la vida y antecedentes de Ida Brown y, finalmente, elaborará un informe en el que se recoge la vida del terrorista Thomas Munk. De este modo, observamos que el saber de Parker es distinto del representado por Nina ${ }^{13}$.

Renzi se constituye en el receptor en el que confluirán los diferentes saberes que circulan en la novela, por lo que a través de la escritura nos muestra cómo ha tenido acceso a la historia oculta tras la muerte de Ida, como él mismo indica: “Anotaba lo que podía, para garantizar lo que había vivido y poder recordarlo" (Piglia, 2013: 144).

Por tanto, la escritura se establece como medio de construcción tanto de la memoria como de la verdad oculta tras los discursos institucionales. Renzi comienza a escribir la historia desde la misma habitación de hotel en la que tenía sus encuentros sexuales con Ida, desde ese lugar situado en las afueras de la ciudad. La verdad encontrará su espacio en la periferia, donde se formó su clandestinidad tratando de escapar a una sexualidad controlada por las instituciones, como veremos más tarde.

La escritura será el medio por el cual se reconstruirá la historia que permanecía oculta bajo el enigma, es decir, la ficción se establecerá como forma de representación de la verdad. Observamos este hecho en "La loca y el relato del crimen", donde Renzi encuentra el modo de expresar la verdad a través de la ficción, la creación del relato será el único medio capaz de mostrar cuál es la versión oculta tras el discurso de la ley.

Otra clave en referencia al uso de la escritura y al lugar de la verdad, en oposición a las pretensiones institucionales, la encontramos en Blanco Nocturno. Como hemos visto, el conflicto surgido entre el comisario Croce y el fiscal Cueto revelará la contraposición en la que observaremos las dos caras de la ley: por un lado, la de Croce y su afán por resolver el caso a través de la investigación de la

\footnotetext{
${ }^{13}$ En las palabras de Parker observamos las claves tanto de su labor con relación al Estado, como de la naturaleza del poder en su país: "Hay dos Estados Unidos, dijo Parker. Uno, visible, el país en el que soy ciudadano que vota [...] Y otro subterráneo, con un poder central sin control, que liquida todo lo que pone en peligro la seguridad nacional. Con ese poder oculto él tenía que hacer sus negociaciones y colaborar para que no lo aplastaran como a un mosquito" (Piglia, 2013: 118).
} 
verdad; por otro lado, la del fiscal Cueto, implicado en una trama de especulación inmobiliaria y que culpará a un inocente por su fragilidad dentro del tejido social.

El comisario Croce, con su defensa de una investigación que esclarezca los puntos oscuros del asesinato de Durán, es relegado de su cargo por la traición de su compañero Saldías y el interés del fiscal Cueto por apartarlo del cuerpo de policía ${ }^{14}$. En su figura hallamos, por un lado, la importancia de constituirse como la excepción de la visión negativa del policía en el género; Croce es un comisario que lucha por un acceso total a la verdad, sin atender a intereses políticos, como él indica: "Yo limpié la provincia de los caudillos políticos y me quedé más solo que Robinsón...” (Piglia, 2010: 178).

Por otro lado, destacamos que en su fijación por la solución del caso recurre a la escritura de anónimos y al encierro: decide ingresar en un manicomio, ya que considera que este es un lugar desde el que poder comprender la realidad, como él mismo indica: "De vez en cuando hay que estar en un loquero, o hay que estar preso, para entender cómo son las cosas en este país” (Piglia, 2010: 177). En su personaje se produce la articulación entre: verdad, escritura, locura y encierro; por lo que será uno de los personajes clave por su situación de clandestinidad en relación con su búsqueda legítima de la verdad ${ }^{15}$.

Es relevante considerar que desde la fundación del pueblo, existe una tradición de anónimos en los que se denuncia una realidad oculta a la opinión pública; Croce será el heredero de dicha tradición, en la que la verdad adquiere un lugar en la clandestinidad y el aislamiento, su posesión será un factor de peligrosidad para sus defensores.

Asimismo, en Croce se manifiestan ciertos rasgos de locura, ya que indica que escucha voces que le dictan sus anónimos, por lo que podemos establecer cierto paralelismo con Echavarne, la loca que aparece en "La loca y el relato del crimen" y también en Respiración artificial; en esta última, como indica Nuria Girona: "Es una loca, depositaria de un saber negado, para quien lo real no pasa por la ley del lenguaje [...] El discurso delirante siempre habla de algo relacionable con la verdad histórica del sujeto" (Girona, 1995: 139). Si bien, aparentemente, el grado de enajenación difiere, observamos que en los discursos de personajes que representan ciertos modos de locura se da una relación con la verdad; en la loca encontramos un lenguaje delirante que encierra una verdad; en Croce un discurso

\footnotetext{
${ }^{14}$ Sobre la figura de Croce como detective y la novela Blanco nocturno remitimos al artículo de Gonzalo Lizardo: "Blanco nocturno y los paradigmas de la novela policiaca"(2013).

${ }^{15}$ Como indica el narrador: "Croce había retomado la tradición de los anónimos para hacer saber que estaba disconforme con el giro de los acontecimientos y con los manejos turbios del fiscal Cueto. Como hacía siempre cuando estaba en minoría absoluta, se había replegado al hospicio del pueblo para enviar tranquilo desde allí sus mensajes anónimos con sus elaboradas hipótesis sobre los hechos” (Piglia, 2010: 191).
} 
Antonio García del Río. Clandestinidad y periferia...

fragmentario, anónimo y aislado que establece un nexo directo con la realidad con el fin de atacar al discurso institucional.

En Blanco nocturno, a partir de la relación entre Croce y Renzi y sus diálogos hallaremos una reflexión en la que se planteará una evolución dentro del género policial, mediante la cual podremos comprender la vinculación de las ficciones de Piglia con los usos y su hipótesis de evolución del género. Renzi indica lo siguiente:

La investigación no tiene fin, no puede terminar. Habría que inventar un nuevo género policial, la ficción paranoica. Todos son sospechosos, todos se sienten perseguidos. El criminal ya no es un individuo aislado, sino una gavilla que tiene el poder absoluto. Nadie comprende lo que está pasando; las pistas y los testimonios son contradictorios y mantienen las sospechas en el aire, como si cambiaran con cada interpretación. La víctima es el protagonista y el centro de la intriga; no ya el detective a sueldo o el asesino por contrato (Piglia, 2010: 284-285).

La incursión de esta reflexión metaliteraria se convertirá en una clave de lectura para comprender los usos que el autor hace del género. Piglia, en su artículo "La ficción paranoica" (1991) propone un nuevo estado de la novela policial, mediante la evolución del género desde sus inicios con Poe hasta la aparición del detective de la serie negra, como Marlowe, y la relación entre enigma y narración como clave del policial.

La propuesta de Piglia se fundamentará sobre dos ejes: la idea de amenaza y el delirio interpretativo (Piglia, 2011: 232-233). No debemos entender ambos factores solo como una cuestión que afecte al contenido de la obra, sino que se plasmará en la forma narrativa que adquieren los relatos. Como indica Piglia en relación con su propuesta: “definir este nuevo estado del género como ficción paranoica, utilizando un término en su acepción no estrictamente psiquiátrica sino como una manera de acercarnos al problema de definir una forma que sea a la vez un contenido" (Piglia, 2011: 228).

Para ello, vamos a observar qué nos indica al autor acerca de esos dos aspectos, en primer lugar respecto a la amenaza:

Uno es la idea de amenaza, el enemigo, los enemigos, el que persigue, los que persiguen, el complot, la conspiración, todo lo que podamos tejer alrededor de uno de los lados de esta conciencia paranoica, la expansión que supone esta idea de la amenaza como un dato de esa conciencia (Piglia, 2011: 232).

En segundo lugar, respecto al delirio interpretativo:

El otro elemento importante en la definición de esta conciencia paranoica es el delirio 
Antonio García del Río. Clandestinidad y periferia...

interpretativo, es decir, la interpretación que trata de borrar el azar, considerar que no existe el azar, que todo obedece a una causa que puede estar oculta, que hay una suerte de mensaje cifrado que "me está dirigido". La mirada de Sherlock Holmes, de Dupin, que mira el conjunto social como una red de signos que le están dirigidos a él para poder descifrar ese secreto a través de una suerte de mensaje que es necesario interpretar (Piglia, 2011: 232).

Así pues, bajo estos dos conceptos se desarrollan gran parte de sus obras. Como hemos podido comprobar, la amenaza es el sentimiento constante que fluye detrás de cada trama, puesto que todos los personajes se sienten amenazados por alguien o algo. Las acciones de cada personaje están sometidas a un tipo de poder y control que los sitúa a un lado u otro de la ley, no solo a través de un determinismo de orden social, sino que el control es ejercido sobre las conductas y los saberes.

En este sentido, hemos comprobado que a través de la lectura se establece un tipo de saber que amenaza y es amenazado, es decir, amenaza con la verdad y su acceso a ella, y es amenazado porque es un método que confrontará con los saberes del Estado y pondrá en peligro su discurso normativo, de modo que aquel personaje que cuente con ese medio de acceso a la verdad, si lo usa en contra de la voluntad institucional se verá relegado a una situación de clandestinidad que lo marcará durante toda la historia.

De este modo, si atendemos a la naturaleza del detective como individuo alejado de las instituciones y que, en nuestro caso, usa la lectura como técnica, debemos tener en cuenta las siguientes palabras de Piglia: "El detective es una figura, entonces, que está en tensión con el mundo del Estado, con lo que- con una ironía seguramente voluntaria- se llama la inteligencia del Estado" (Piglia, 2011: 227).

Por otro lado, ese delirio interpretativo emana de la diversidad de personajes que llevan a cabo procesos de investigación, todos investigan algo y usan determinados medios para ello ${ }^{16}$. Cada personaje trata de interpretar todo cuanto le rodea, en busca de las claves que den con la solución del enigma que a cada uno le es planteado.

Podríamos pensar que dicha multiplicidad de procesos e investigadores tiene su reflejo en la propia escritura de los textos, puesto que en las obras encontraremos representada la heterogeneidad discursiva que se hace efectiva a través de la presencia todos los personajes. Encontramos el registro periodístico, los informes médicos y de investigación, la versión de la policía, la crítica literaria, la reflexión lingüística, la escritura personal bajo la forma de diarios, los anónimos, las voces de los presos y

${ }^{16}$ Como señala Jorge Fornet: “Casi todos los personajes importantes se transforman en detectives, rastreando las huellas de crímenezs que tal vez no ocurrieron; lo importante, de hecho, no es el crimen mismo sino el rastreo de las pistas" (Fornet 2007: 96). 
la voz de la locura, entre otros.

El delirio interpretativo, bajo las tramas de enigma, deja salir a la superficie toda una serie de discursos que ponen en duda una visión uniformadora de la sociedad. Bajo una misma ficción caben todas las escrituras, que al fin y al cabo, no dejan de representar a todas las voces ${ }^{17}$.

De este modo, comprobamos cómo el hecho de recoger los diversos tipos de escrituras, que no dejan de representar las diversas voces que subyacen de los textos, consigue negar un discurso autoritario y con pretensiones totalizadoras, que a través del uso del género policial estará identificado con la policía y el Estado. Cada ficción encierra todas las ficciones y todos los discursos, por lo que, al fin y al cabo, nos permite observar las distintas caras de la realidad bajo una amplia gama de perspectivas.

\section{Reflejos en las estructuras narrativas}

Como hemos indicado respecto a la ficción paranoica, los conceptos de amenaza y de delirio interpretativo no permiten un planteamiento unívoco u homogeneizador de la escritura, por lo que la concepción paranoica podrá comprenderse también a través de las estructuras narrativas y los registros que interactúan en las novelas.

Si atendemos al artículo de Andrea Torres Perdigón (2013: 133-153) observamos que las novelas analizadas en nuestro trabajo pertenecen a un segundo periodo de la producción de Piglia. Según Torres Perdigón esta etapa estaría encabezada por obras como Plata quemada y Blanco nocturno y alejada de los planteamientos y estructuras narrativas de corte más vanguardista y experimental empleados en Respiración artificial (1980) y La ciudad ausente (1992), bajo la posible influencia de la concepción literaria de Macedonio Fernández.

De este modo, nos encontramos ante un giro en la narrativa de Piglia que tiende hacia una mayor narratividad a partir de la reducción de la reflexividad y el fragmentarismo característico de sus obras anteriores. Como indica Torres Perdigón respecto a la evolución:

la aparición de estas digresiones es cada vez menor en el narrador de Blanco nocturno, como si Piglia estuviese intentando alejarse cada vez más de ese tipo de narración explícitamente

\footnotetext{
${ }^{17}$ Podemos traer aquí una cita de Nuria Girona respecto a la polifonía en Respiración artificial: «la orquestación de voces y escrituras escapa de la omnisciencia del demiurgo; desborda su potestad al concederles un lugar a todas ellas. Las comillas o la cursiva que aparecen en el texto son las marcas de traslación discursiva, que señalan una voz ajena insertada en el texto, las marcas que resaltan la alteridad de una segunda enunciación» (Girona, 1995: 133).
} 
Antonio García del Río. Clandestinidad y periferia...

reflexiva, para volver a un narrador extradiegético tradicional [...] es, en efecto, como si su búsqueda actual estuviera volviendo a una forma narrativa más tradicional (Torres Perdigón, 2013: 150) ${ }^{18}$.

Podemos constatar este cambio en las novelas que hemos estudiado, tanto Plata Quemada como Blanco nocturno hacen uso de una voz narrativa extradiegética, de apariencia heterodiegética, según la tipología de Genette ${ }^{19}$, es decir, son narradores aparentemente no involucrados en la diégesis que a partir de su posición externa serán los cohesionadores tanto de la historia como de los materiales empleados en la narración.

En Plata Quemada encontramos una voz que teje la historia a partir de la recolección de diversos documentos y testimonios, una voz que durante todo el libro aparece indeterminada y que, sin embargo, se identifica en el epílogo y nos muestra cómo accedió a la historia a través de un encuentro con Blanca Galeano, novia de uno de los atracadores. Como indica Adriana Rodríguez Pérsico respecto a la multiplicidad de voces y materiales con los que trabaja la novela:

El relato trabaja con la diseminación de distintas voces que se responden unas a otras en una especie de coro polifónico, o quizás, trágico. Una cantidad de voces se encastran: la autoridad, la de la dóxa, la del delito, la periodística, la del cronista, las voces interiores de la locura. (Rodríguez Pérsico, 2004: 119)

No obstante, ella misma comenta que dicha pluralidad es engañosa: «la oralidad vela un uso peculiar de la polifonía, a contrapelo de las modas, que desmiente cualquier lógica que postule igualdad o la horizontalidad de estas voces múltiples» (Rodríguez Pérsico, 2004: 120). Por lo tanto, podemos pensar que no estamos ante un tipo de estructura polifónica al modo de Respiración artificial, ya que detrás de todas las voces encontramos una voz que las orquesta, las dota de un ritmo y de un sentido.

Desde nuestro punto de vista, a pesar de que el relato esté dirigido por una voz, el hecho de que dentro de la novela se inserte el relato periodístico, la voz de los delincuentes, de la policía, los informes médicos o la declaración de los testigos, se convierte en un ataque a un discurso monológico, que en la novela viene caracterizado por el Estado; por lo que detrás de esta orquestación de materiales se halla una crítica a los discursos estatales que, además, se evidencia a través del uso del género policial.

Sin embargo, no podemos obviar que a pesar de la presencia de un narrador que, de algún modo,

\footnotetext{
${ }^{18}$ Sobre el desarrollo en la evolución de la narratividad de Piglia remitimos al artículo de Andrea Torres Perdigón (2013: 133-153).

19 Véanse las categorías establecidas por Genette en Figuras III(1989).
} 
Antonio García del Río. Clandestinidad y periferia...

jerarquiza dichas voces, las enfrenta y nos presenta un relato modalizado, encontramos un esfuerzo en el trabajo de representación de los distintos registros y voces. Así pues, no dejará de representar las diversas perspectivas que giran en torno al conflicto de la novela, sea de forma modalizada o no.

Quizá, debamos pensar que detrás de la evolución planteada por Torres Perdigón se halla un esfuerzo de comunicabilidad, un intento de explicitar lo indecible que se esconde detrás de las tramas, a través de unas estructuras narrativas que otorgan una mayor transparencia y legibilidad a los lectores.

El trabajo sobre un eje diegético basado en la interrogación conlleva a una reelaboración de la historia, que trata de interpelar la lógica de la causalidad a través de los procesos de investigación ya estudiados. Por consiguiente, observamos cómo el acercamiento a unas formas narrativas alejadas de la fragmentación extrema permite responder a la necesidad de comprensión de la realidad que plantean las novelas. $\mathrm{O}$, al menos, tratan de trasladar a la propia estructura narrativa la posibilidad, a menudo frustrada, de esa comunicabilidad de la experiencia que Benjamin vincula al arte de narrar.

Así pues, mientras en Plata Quemada y Blanco nocturno se recurre a un narrador extradiegético, ajeno a la historia, debemos tener en cuenta que En el camino de Ida se da un paso hacia adelante. En esta novela, Piglia planteará un nuevo cambio, ya que la posición del narrador difiere de las dos anteriores, nos encontramos ante un narrador intradiegético-autodiegético, en la figura de Emilio Renzi, que nos presentará la historia desde su propia experiencia, es decir, trabajará los acontecimientos desde su subjetividad.

Este tipo de narrador nos muestra un punto de vista modalizado de los acontecimientos, por lo que podríamos pensar que en la obra solo hay lugar para su visión. Sin embargo, a través de la dialéctica entre diferentes personajes investigadores comprobamos cómo, a pesar de que el relato se construye a partir de una perspectiva concreta, se presentan una gran cantidad de puntos de vista a través de los diferentes registros escritos empleados.

En la novela, observamos la reflexión sobre el proceso de escritura que el personaje ha llevado a cabo sobre la propia novela, por lo que, a pesar de no ser una novela experimental al modo de La ciudad ausente, en muchos momentos de la narración se escora hacia la autorreflexividad y hacia la metanarrativa. Encontramos también la recreación de las charlas entre Renzi y los investigadores, los informes realizados sobre Ida y Thomas Munk, la entrevista con el terrorista, la reflexión literaria e, incluso, la visión de la policía a través de las informaciones proporcionadas por el detective privado.

Tal vez, uno de los hechos más destacados se halle en que la continua reflexión crítica sobre la literatura a través de Renzi, sus alumnos en el seminario y su vecina rusa, sea uno de los medios de acceso 
a la verdad empleado para la resolución del caso.

De este modo, observamos cómo a pesar de narrar desde un lugar concreto de la enunciación, nunca se dejan de lado los diferentes registros, escrituras y voces que emanan del resto de los personajes. El hecho de tener en cuenta esta diversidad, aunque filtrada por el narrador, será una forma de rebelión ante el discurso autoritario representado por el Estado, por lo que podríamos pensar que Piglia en sus novelas escenifica una lucha contra el monologismo institucional ${ }^{20}$.

Por lo tanto, en Piglia tienen cabida todos los lenguajes, las escrituras y los grupos sociales recrea la voz del delincuente, la de la locura, la literaria e, incluso, la de la policía, es decir, podemos pensar que en sus obras como constructos heteroglósicos. Como indica Tatiana Bubnova sobre Bajtin y la heteroglosia:

La realidad del lenguaje como acción en la versión bajtiniana es la de pluralidad de lenguajes sociales y de discursos ideológicos que constituyen un medio dinámico de la heteroglosia (pluridiscursividad) y remite a la oralidad. Es un mundo poblado de sonido del discurso oral, con sus modulaciones, acentos y entonaciones, cada uno de los cuales es portador de los matices del sentido social y personalizado situacional (Bubnova, 2006: 108)

En este sentido, es relevante considerar que en las obras de Piglia la inserción de los distintos discursos y registros suele darse a través de la introducción de la oralidad por medio de la escritura en la narración; en este factor, destaca además la relevancia del periodismo, debido a la traslación de los testimonios orales a la escritura por mediación de Renzi. A modo de conclusión encontramos el reflejo de esta cuestión en las palabras de Nuria Girona sobre Respiración artificial:

Bajtin considera también que sólo el discurso autoritario, el discurso dogmático que pretende revelar una verdad inmodificable es completamente ajeno a esta efervescencia de voces, ya que no admite pluralidad de punto de vista [...] En el otro extremo, el discurso literario, el discurso de Piglia que burla los dictémenes de un decir del poder, en el que todas las citas se dan cita, dialógico por excelencia. Buena parte se articula como discurso mostrado, recogido de otra voz y, a la vez, de otras escrituras (Girona, 1995: 132-133).

\footnotetext{
${ }^{20}$ Respecto a esta cuestión consideramos pertinente la observación de Teresa Orecchia Havas sobre el trabajo de Piglia sobre la oposición entre relato literario y los relatos estatales en Respiración Artificial, como indica la autora: "Así se dedicó a estudiar el polimorfismo del discurso narrativo, considerando que su principal objetivo es ideológico y oponiendo el dialogismo propio a la literatura al discurso monológico del poder autoritario" (Orecchia Havas, 2005:1215-1216). Beatriz Sarlo trabajó también esta idea a propósito de Respiración Artificial, en el artículo: "Política, ideología y figuración literaria" en el libro: Ficción y política: la narrativa durante el proceso militar.
} 


\section{Sexualidad, ley y encierro}

Piglia en El último lector recoge una serie de consideraciones sobre «Los crímenes de la rue Morgue», entre las cuales indica que:

La idea de que la sospecha se construye sobre el prejuicio es trabada con mucha eficacia por el género. El primer sospechoso es el otro social, aquel que pertenece a la minoría que rodea el mundo blanco, dentro del cual se están desarrollando las versiones paranoicas de lo que supone la amenaza (Piglia, 2005: 85).

La sexualidad es una cuestión abordada de manera especial en las obras de Piglia ya que, por un lado, la condición sexual de los individuos y sus relaciones sexuales determinarán, en cierto modo, la relación con la ley y su lenguaje, ubicándolos en la clandestinidad. Por otro lado, comprobamos cómo inciden los espacios cerrados y sometidos al control en las relaciones sexuales de los personajes de las obras $^{21}$.

La homosexualidad es uno de los rasgos que condicionará a los personajes en las investigaciones llevadas a cabo por la policía. En Plata quemada, tras la pareja de atracadores formada por Dorda y Brignone, se encuentra una relación con los lugares de encierro y una repudia a su condición por parte de los agentes policiales.

En primer lugar, tenemos a Dorda, el cual procede de una familia trabajadora de inmigrantes italianos ligados al campo; su figura se caracteriza por su conducta y por las continuas entradas y salidas de calabozos y establecimientos psiquiátricos. Tras la comisión de un asesinato ingresó en un psiquiátrico, donde el médico de guardia: “Lo mandó al pabellón de los locos tranquilos y la primera

${ }^{21}$ Piglia en el apartado «Conversación en Princeton» del libro Crítica y ficción (2001: 205-206) responde a una pregunta sobre el papel que juega la sexualidad en su obra, en concreto, el lugar que ocupa la homosexualidad en sus novelas y relatos. El autor responde que parte de los relatos de su libro La invasión abordan climas de tensión sexual en ámbitos definidos por redes masculinas. Sin embargo, indica que lo que él ve son circulaciones del deseo, es decir, más allá de una conducta sexual concreta con unas consideraciones por parte de la sociedad, encuentra en ámbitos como la cárcel, el ejército o el deporte “un espacio de circulación entre cuerpos” donde se da «la competencia extrema, los desafíos, los sentimientos desplazados, no mostrar lo que se siente». Por lo tanto, observamos cómo en su obra la sexualidad aparece reflejada en lugares de encierro, pero también consideramos importante mostrar cómo la ley aborda la condición sexual de los individuos o, mejor dicho, cómo instrumentaliza su sexualidad para marcar a ciertos sujetos con relación a un crimen. 
noche se lo cogieron tres enfermeros" (Piglia, 2012: 67).

Así pues, la caracterización de Dorda es introducida a través de los diagnósticos del Dr. Bunge; lo relevante de estas descripciones consiste en la base médica que las respalda, son consideraciones de un especialista que piensa en su paciente como un sujeto incurable, peligroso para la sociedad, y para ello no solo acude a sus condiciones patológicas, sino también a su condición sexual, considerada como inversión ${ }^{22}$.

En segundo lugar, encontramos al Nene Brignone, hijo de un empresario del sector construcción, por lo que podemos contrastar su origen aburguesado con los orígenes provincianos de Dorda. Mientras su compañero, Dorda, padece problemas mentales antes de llevar a cabo sus primeros delitos, Brignone con tan solo diecisiete años, accede al mundo del crimen de forma accidental, tras acompañar a unos amigos que mataron a un hombre en un intento de robo.

Su ingreso en prisión es el detonante de la desgracia familiar y personal. Por lo que en Nene observamos, a través de sus propias palabras, el efecto que produce la vida en prisión: "En la cárcel me hice puto, drogadicto, me hice chorro, peronista, timbero, aprendí a pelear a traición” (Piglia, 2012: 85-86).

El personaje nos habla de una educación negativa a través de su paso por la cárcel, en sus palabras se evidencia la introducción en la delincuencia y el contacto pleno con la marginalidad, la prostitución y la locura. La cárcel es el elemento perturbador de Brignone, sin embargo, no lo es solo por el contacto entre individuos problemáticos, sino por el sistema penitenciario instaurado en el control y aislamiento de los presos.

Observamos que la pareja formada por Brignone y Dorda nos muestra las dos caras de la moneda: dos sujetos de distinta clase social que encuentran en el crimen y el presidio su punto de encuentro. Como indica el narrador: "se habían conocido en la cárcel de Batán, un basurero, cayeron juntos en un pabellón de invertidos. Putos, violetas, reinas...Toda la mezcla” (Piglia, 2012: 68). La pareja es vista como un único cuerpo: el Nene la cabeza, Dorda la fuerza.

La relación entre estos dos hombres nace del aislamiento, alejada de cualquier parámetro o norma, fruto del desarraigo en el que han sido inmersos. De este modo, nos interesa detenernos en el otro lado:

\footnotetext{
${ }^{22}$ Algunas de las evaluaciones del doctor son las siguientes: un "esquizo, con tendencia a la afasia" (Piglia, 2012: 64), "obseso sexual, perverso polimorfo, [...] psicótico, invertido" (2012: 71), que escucha voces de mujeres que lo llaman "Guacha, Yegüita” y que permanecía inmóvil "para que nadie se diera cuenta de que era una mujer” (Piglia, 2012: 65).
} 
Antonio García del Río. Clandestinidad y periferia...

la ley y su lenguaje, es decir, debemos atender al tratamiento que reciben por parte de la policía y las instituciones.

La multiplicidad de voces que recoge la novela plasma, a través de las figuras del doctor Bunge y del comisario Silva, la postura del Estado acerca de la delincuencia y la sexualidad por medio de la utilización del discurso médico para marcar a estos individuos como enfermos peligrosos ${ }^{23}$.

El doctor Bunge representa al campo de la psiquiatría, sus consideraciones son presentadas como diagnósticos a través tanto del uso directo de su voz, como de la extracción de datos de los informes clínicos de Dorda. Bunge diagnostica como anómala la condición de Dorda, fue “el primero que le empezó a decir que tenía que ser igual a todos. Que se buscara una mujer, que hiciera una familia" (Piglia, 2012: 203).

Por lo tanto, el hecho de que a Dorda le gustaran los hombres y las voces que escuchaba fruto de su enfermedad son los síntomas claros que Bunge debe tratar, de modo que tras la observación es necesario el tratamiento: "Por eso lo trataban con las inyecciones y las pastillas en el hospital para curarlo, para volverlo sordo, para sacarlo del pecado de la sodomía” (Piglia, 2012: 204).

El comisario Silva, el representante de la policía, también empleará el lenguaje médico para calificar a la pareja de fugitivos. En el asalto final al piso franco en Uruguay, donde se establece la confrontación entre ley y crimen, Silva, tras llamar enfermos mentales a los asaltantes, se enfrenta con Renzi, quien le indica que en el periodismo no está bien visto matar a enfermos, sino llevarlos a centros de tratamiento.

Este es el momento en el que aflora la verdadera postura del comisario, no hay negociación posible, tan solo el exterminio o el aislamiento son la solución. De ellos indica lo siguiente: "Estos señores son psicópatas, homosexuales [...] Casos clínicos, basura humana. [...] hijos de alcohólicos, son resentidos, carne de frenopático, [...] son una manada de lobos acorralados en una casa" (Piglia, 2012: 179).

De este modo, observamos en ambas figuras la postura por parte de dos órganos que fundamentan

${ }^{23}$ Beatriz González Stephan, en su artículo "El cuerpo salvaje de la nación: ciudadanías desplazadas (Siglo XIX)" (1996) indica que el uso del discurso clínico en el proyecto modernizador en la América Latina del siglo XIX “permitió pensar- dentro de esta lógica positivista- a ciertos cuerpos sociales en términos patológicos, [...] La metáfora biológica y clínica permitió múltiples maniobras conceptuales, donde la enfermedad terminaba por asociarse con la suciedad, la indigencia, las familias pobres, la homosexualidad, la masturbación, el adulterio, la prostitución” (G. Stephan, 1996: 7-9). Por lo tanto, observamos la influencia de este pensamiento y del uso del discurso clínico en las palabras de Bunge y del comisario. 
Antonio García del Río. Clandestinidad y periferia...

el poder. Debemos cuestionarnos si el crimen es un pretexto para la condena a cierto tipo de conductas $^{24}$. Tanto en sus palabras como en los medios coercitivos empleados con Dorda y Brignone, advertimos que la única solución es el aislamiento, el confinamiento en centros psiquiátricos o prisiones. Su condición es tratada como una enfermedad que pone en peligro el conjunto de la sociedad, su cuerpo.

Michel Foucault, en el capítulo "Derecho de muerte y poder sobre la vida” en su obra La voluntad del saber (1976), el primer tomo de Historia de la sexualidad, analiza la transformación, a partir del siglo XVIII, de los mecanismos de poder que dieron lugar a la evolución de un control del Estado basado en la muerte hacia un control ejercido directamente sobre la vida, a través del inicio de la era del biopoder $^{25}$.

Este cambio de postura, que implicaba la asimilación de la población como cuerpo, conllevó a que el sexo fuera considerado como "blanco central para un poder organizado alrededor de la gestión de la vida más que la amenaza de muerte” (Foucault, 2006: 156). En torno a él se establecerán una serie de controles al servicio de la distribución de la sociedad, por lo que la sexualidad se convierte en materia política, "matriz de las disciplinas y principio de las regulaciones". Foucault indica sobre el siglo XIX que:

La sexualidad es perseguida hasta en el más ínfimo detalle de las existencias; es acorralada en las conductas,[...] se convierte en tema de operaciones políticas, de intervenciones económicas (mediante incitaciones o frenos a la procreación), de campañas ideológicas de moralización o de responsabilización. (Foucault, 2006: 155).

Las novelas de Piglia tematizan directamente la normativización biopolítica, relacionándola con su análisis de los dispositivos de poder y del modo en que estos atraviesan el cuerpo y la subjetividad. Las figuras de Dorda y Brignone, en ese sentido, escenifican la vivencia de una sexualidad compleja, dentro de un proyecto más amplio de analizar los modos de la circulación del deseo, en lugares donde las relaciones son eminentemente masculinas, como hemos citado anteriormente. De ese modo nos permite comprobar otro trasfondo, la visión de la sexualidad bajo la óptica del poder.

La tensión sexual que surge en esos espacios cerrados se vincula con la exclusión a la que estos

${ }^{24}$ En el artículo de Edgardo H. Berg "Fuera de la ley" (2004: 213-222) encontramos un análisis sobre el crimen en Plata Quemada y la figura de los dos asaltantes.

${ }^{25}$ Foucault, sobre el bio-poder indica lo siguiente: "fue, a no dudarlo, un elemento indispensable en el desarrollo del capitalismo; éste no pudo afirmarse sino al precio de la inserción controlada de los cuerpos en el aparato de producción y mediante un ajuste de los fenómenos de población a los procesos económicos" (Foucault, 2006: 149). 
personajes son sometidos por unas conductas que, según la ley, hacen peligrar el cuerpo social. Dichas conductas no productivas son recluidas en los márgenes que el poder establece, las prisiones y los centros psiquiátricos, tratando de hacerlas invisibles al resto. El crimen hace que salgan a flote, mostrándonos los medios empleados para el tratamiento de dichos individuos.

La homosexualidad no es un hecho exclusivo de Plata quemada, sino que aparece en otras obras de Piglia. En Blanco nocturno encontramos una conexión entre la figura de Yoshío Dazai y la de Antúnez en "La loca y el relato del crimen", ambos son los inocentes inculpados por asesinato debido a la fragilidad de su condición social.

Yoshío, un "nikkei: un argentino de origen japonés” (Piglia, 2010: 77), es el conserje del hotel donde se hospeda la víctima y mantiene una relación de amistad con ella. Su personaje representa a la figura del otro social, puesto que se caracteriza por dos rasgos: su condición de extranjero, por su procedencia japonesa, y su homosexualidad. Estos factores jugarán en su contra en la investigación del crimen de Tony Durán.

Así pues, como Antúnez, se convierte en el chivo expiatorio. Su inocencia solo será defendida por el comisario Croce, quien es consciente de que el fiscal Cueto pretende que el caso se resuelva como un crimen sexual, con el fin de enmascarar una trama de especulación inmobiliaria, en la que él mismo está implicado, con el objetivo de hacerse con los terrenos de una fábrica de Luca Belladona.

Yoshio es encarcelado y en su celda escucha los cantos de otros presos. Estas voces se convierten en una especie de oráculo para Yoshio, en ellas escuchará la realidad de su situación y evidenciarán su fragilidad ante la ley.

Un ejemplo representativo de dichas voces sería la siguiente: «A un vecino propietario/ un boyero le mataron/y aunque a mí me lo achacaron / salió cierto en el sumario»; otro extracto representativo 
Antonio García del Río. Clandestinidad y periferia...

sería este: «el hombre que dentre aquí, / deje afuera la esperanza...»(Piglia, 2010: 172-173)²6.

Finalmente, Yoshio es tomado como moneda de cambio para la resolución del caso; el fiscal Cueto propondrá a Luca Belladona, un pacto en el que se condenará a Yoshio de asesinato a cambio de recuperar el dinero de la herencia familiar que portaba la víctima a su llegada al pueblo. De este modo, la decisión de Luca antepone el dinero a la verdad y su decisión trágica condenará a un inocente a la prisión.

Así pues, Yoshio solo será en un daño colateral bajo el sistema de relaciones especulativas que urde el fiscal. Tan solo será una víctima más del juego codicioso y despiadado de los intereses económicos; su fragilidad lo llevará a ser un cuerpo inocente, que aislado en una celda, escuchará las voces que le recordarán su realidad.

Por otro lado, observamos también el tratamiento de la sexualidad a partir de un uso del género policial en El camino de Ida. Las circunstancias que rodean la misteriosa muerte de la profesora universitaria Ida Brown y sus relaciones con Emilio Renzi nos permitirán observar la vinculación que las relaciones sexuales establecen con los espacios donde transcurre la novela, por lo que quedará determinada una clandestinidad sexual que tendrá que buscar lugares al margen donde poder realizarse.

El lugar donde comenzará la relación entre ambos personajes será el campus universitario, el cual actuará como centro donde la envidia y el prestigio se configuran como fuerzas opresoras en las

\footnotetext{
${ }^{26}$ No podemos evitar relacionar este pasaje, que refleja el aislamiento del preso, con la descripción en Plata quemada, a través de Brignone, de su experiencia en prisión: "el odio es lo que te mantiene vivo, te pasás la noche sin poder dormir, en la jaula, mirando la lamparita en el techo, [...] prendida las veinticuatro horas para que te puedan espiar, para obligarte a tener las manos afuera de las cobijas, pasa un valerio y levanta la mirilla y te ve ahí, despierto, pensando. [...] Y te vuelven loco, tarde o temprano. Si estás todo el tiempo pensando. [...] lo peor es que te tienen encerrado y no vivís, estás como muerto y ellos te hacen hacer lo que quieren y esa vida vacía a la larga te quiebra, te llenás de rencor, te envenena" (Piglia, 2012: 87-89). A través de las voces recogidas en estas novelas observamos cómo la sensación de encierro es un factor determinante en los individuos que se ven recluidos en las prisiones. Al respecto, Michel Foucault ha tratado estos aspectos en diversas obras y entrevistas; en una conversación con Deleuze titulada como "Un diálogo sobre el poder" (1972) indica lo siguiente: "Meter a alguien en la prisión, mantenerlo en la prisión, privarle de alimento, de calor, impedirle salir, hacer el amor... ahí tenemos la manifestación del poder más delirante que uno pueda imaginar [...] La prisión es el único lugar donde el poder puede manifestarse en su desnudez, en sus dimensiones más excesivas, y justificarse como poder moral" (Foucault, 2012: 35). Estas experiencias de control y aislamiento vividas en los centros penitenciarios, y psiquiátricos, se nos muestran como negativas a través de las voces de los personajes: el sometimiento total a la vigilancia es un elemento perturbador que conllevará una serie de trastornos en sus personalidades.
} 
Antonio García del Río. Clandestinidad y periferia...

relaciones personales ${ }^{27}$, como indica Renzi: “Los campus son pacíficos y elegantes, están pensados para dejar afuera la experiencia y las pasiones pero corren por debajo altas olas de cólera subterránea: la terrible violencia de los hombres educados" y menciona que: "Las universidades han desplazado los guetos como lugares de violencia psíquica” (Piglia, 2013: 35).

Ese centro opresor condiciona la relación entre Ida y Renzi. Tras un encuentro en el tren, camino de Nueva York, hallan en la ciudad el refugio donde poder alejarse del control del campus. El apartamento de Ida en el Village es el lugar donde transcurre su primera e intensa relación sexual. Posteriormente, Ida, ante el temor a la opinión pública, le indica a Renzi que serían amantes clandestinos $^{28}$. El sexo se establece como actividad transgresora a la represión y la ciudad como lugar de fuga, en el que se encuentra el imposible anonimato del campus.

Su relación dentro de la universidad no debe exceder del trato académico, por ello sus encuentros se darán en la periferia, en un hotel situado en las afueras de la ciudad: "tal vez era un lugar destinado a las citas clandestinas de los amantes furtivos de la zona” (Piglia, 2013: 67). La habitación de ese hotel será el lugar donde Renzi escribirá su historia, es decir, la escritura se vincula a ese afuera relegado a la clandestinidad; en cierto modo, se convertirá en una actividad que plasma todo aquello que el centro no permite.

Situar en la periferia el marco para sus relaciones será una forma de evasión ante las miradas represoras que proceden tanto de alumnos, compañeros y superiores, como de sí mismos. Podemos pensar que gran parte de la censura que emana del campus es, en realidad, una forma de autocensura; Ida es su propio centro represor, es decir, ejerce en su vida una vigilancia que, tal vez, es superior que la que cualquiera podría ejercer.

Por consiguiente, la asunción de un estado de vigilancia por parte del propio individuo nos

\footnotetext{
${ }^{27}$ Debemos tener en cuenta la topografía que Renzi introduce al inicio de la novela: "El pueblo era espléndido [...] Residencias con amplios jardines abiertos, ventanales de cristal, [...] Era como estar en una clínica psiquiátrica de lujo, [...] La vida peligrosa parecía estar fuera de ahí” (Piglia, 2013: 15).De este modo, bajo la apariencia de este locus amoenus residencial y académico se esconde, en realidad, un locus eremus que mostrará su conflictividad a través de las conductas de los integrantes de la comunidad universitaria, sus rencillas, la vigilancia y control que sus miembros imponen sobre sí mismos y el resto.

${ }^{28}$ Como indica Renzi sobre Ida: «El mundo académico era demasiado cerrado, abarcaba demasiado espacio y dejaba poco lugar para otras experiencias, había que construir puntos de fuga y vidas clandestinas para escapar de las formalidades [...] A medida que aumentaban sus logros profesionales [...] sentía crecer en ella la necesidad de sometimiento y humillación» (Piglia, 2013: 63).
} 
Antonio García del Río. Clandestinidad y periferia...

remitirá al concepto de panóptico trabajado por Foucault"29, sobre el que nos indicará que: "Basta una mirada, Una mirada que vigile, y que cada uno, sintiéndola pesar sobre sí, termine por interiorizarla hasta el punto de vigilarse a sí mismo; cada uno ejercerá esta vigilancia sobre y contra sí mismo" (Foucault, 1989: 18).

La aplicación de dicho principio se expande no solo a prisiones, sino que también a centros psiquiátricos, escuelas o cuarteles. En nuestro caso, lo encontramos representado en este complejo universitario, no como forma arquitectónica, sino como principio de poder y control insertado en la mentalidad de sus integrantes. Entre aulas, despachos, relaciones profesionales y personales, son escenificados los entresijos de la "sociedad disciplinaria” de la que nos habla Foucault (2007: 103).

La hostilidad se hace efectiva a través de las miradas, el control se convierte en un rasgo estructural en la ambientación que nos ofrece el narrador. El odio y la vigilancia latente serán una constante en la vida del campus, tal vez, esta evidencia se representa mediante la metáfora de la aparición de un tiburón como mascota en el sótano de la casa de D’Amato. El tiburón es el símbolo de la violencia, el miedo y el poder.

En suma, si bien en la obra la sexualidad no es el tema principal, advertimos que su tratamiento no es inocente. Las relaciones serán una vía para escenificar la red de control que se establece a partir de un espacio tan delimitado como el campus. La vinculación entre espacios y clandestinidad se hace efectiva en la novela en tanto que consideramos la sexualidad como forma de clandestinidad.

En conclusión, comprobamos cómo, en las obras de Piglia, a través del uso de ciertos elementos del policial, como el delito y la confrontación entre ley y crimen, el tratamiento de la sexualidad es asociado a conductas vinculadas con la clandestinidad.

Asimismo, debemos añadir que la clandestinidad siempre estará asociada con determinados espacios que representan lugares de exclusión y control como son las prisiones y los psiquiátricos, ubicados en los márgenes de los centros donde se producen las relaciones sociales y económicas. En esos espacios, el autor trabajará las circulaciones del deseo que nos permitirán observar las posturas y los discursos tanto de la ley como de la clandestinidad.

\footnotetext{
${ }^{29}$ Foucault en La verdad y las formas jurídicas (1978) indica lo siguiente acerca de la concepción arquitectónica del panóptico, ideada por Jeremy Bentham: «era un sitio en forma de anillo en medio del cual había un patio con una torre en el centro. El anillo estaba dividido en pequeñas celdas que daban al interior y al exterior, [...] en la torre central había un vigilante y como cada celda daba al mismo tiempo al exterior y al interior [...] todo lo que el individuo hacía estaba expuesto a la mirada de un vigilante que observaba a través de persianas y postigos semicerrados, de tal modo que podía ver todo sin que nadie, a su vez, pudiera verlo» (Foucault, 2007: 104)
} 
Antonio García del Río. Clandestinidad y periferia...

\section{Conclusiones}

Toda lectura consiste en un acto de investigación, detrás de un conjunto de signos o hechos encontramos la necesidad de su descodificación e inferencia. Por este motivo, la figura del investigador está ligada estrechamente con la figura del lector, su función será leer la realidad y tratar de interpretarla en busca de la verdad; de esta manera, detrás de la lectura y de la investigación se encuentra una verdad multiforme que varía desde la óptica de cada sujeto.

Las novelas de Piglia usan los modelos de investigación como soporte estructural en la creación de los argumentos y de las estructuras narrativas, por lo que el trabajo sobre el enigma planteará la reconstrucción de la historia y la búsqueda de la verdad.

El uso de ciertos esquemas aportados por el policial permitirá a Piglia plantear, a través del crimen y de la figura del detective, una exploración en las complejas relaciones establecidas entre la ley, el crimen y la clandestinidad. Por lo que este uso del género se constituirá como una lectura de los diversos discursos que forman la sociedad.

Como indica Piglia en El último lector: "Lo que se debe leer, lo ilegible, lo que se esconde en la multitud, está asociado con el crimen. Lectura y crimen ya están enlazados” (Piglia. 2005: 83). Los procesos de investigación precisarán de unos medios concretos de acceso a la verdad, en las obras de Piglia, la lectura y la escritura son saberes opuestos a los empleados por la ley; el uso de estas técnicas, a menudo, estará vinculado con la clandestinidad, puesto que cuestionan el poder y la lógica del Estado.

Asimismo, la lectura y la investigación dotarán a las obras de una continua reflexión crítica sobre la literatura y sus aplicaciones, tal y como hemos comprobado a partir de los usos del género y la intuición de un nuevo estadio dentro del policial.

Las obras estudiadas se encuentran en lo que podríamos considerar una segunda etapa en la producción de Piglia, en la que a través del uso de unas formas narrativas alejadas del experimentalismo de sus primeras obras responde a la búsqueda de la comprensión de la realidad y una mayor comunicabilidad que permita hacer visible todo lo que oculta el discurso de la ley y los intereses del Estado.

En definitiva, la narrativa de Piglia entabla una comunicación crítica y directa con la literatura, la historia y los discursos estatales, mostrando los diversos puntos de vista que rodean a un mismo hecho: los efectos del poder sobre la sociedad. 
Antonio García del Río. Clandestinidad y periferia...

\section{Bibliografía}

Berg, Edgardo Horacio (2004). «Fuera de la ley». Rodríguez Pérsico, Adriana (comp.) Ricardo Piglia: una poética sin límites. Pittsburgh: Instituto Internacional de Literatura Iberoamericana: 213-222.

Bubnova, Tatiana. "Voz, sentido y diálogo en Bajtín". Acta Poética vol. 27, n. 1 (2006). México: Red Universidad Nacional Autónoma de México: 97-114.

Fornet, Jorge (2007): El escritor y la tradición. Ricardo Piglia y la literatura argentina, Buenos Aires, Fondo de Cultura Económica.

Foucault, Michel (1989). “El ojo del poder. Entrevista con Michel Foucault”. Bentham, Jeremías: El panóptico. Madrid: Ediciones La Piqueta: 9-26.

Foucault, Michel (2003). Vigilar y castigar. Nacimiento de la prisión. Buenos Aires: Siglo XXI: 11-74.

Foucault, Michel (2006). Historia de la sexualidad, I, La voluntad de saber. Madrid: Siglo XXI: 141-169.

Foucault, Michel (2007). La verdad y las formas jurídicas. Buenos Aires: Gedisa S.A: 93-120.

Foucault, Michel (2012). Un diálogo sobre el poder y otras conversaciones. Madrid: Alianza Editorial: 29-43.

Genette, Gérard (1989). Figuras III. Barcelona: Editorial Lumen: 270-322.

Girona Fibla, Nuria. "Escrituras de la historia, La novela argentina de los años ochenta". Cuadernos de filología XVII (1995). Valencia: Universidad de Valencia.

González Stephan, Beatriz. "El cuerpo salvaje de la nación: ciudadanías desplazadas (Siglo XIX)”. Kipus revista andina de letras $n^{\circ} 5$ (1996): 3-18.

Hoveyda, Fereydoun (1967). Historia de la novela policiaca. Madrid: Alianza Editorial.

Lizardo, Gonzalo. "Blanco nocturno y los paradigmas de la novela policiaca". FILHA. Revista de la Maestría en Investigaciones Humanísticas y Educativas, $\mathrm{n}^{\circ} 10$ (2013).

Mattalia, Sonia (2008). La ley y el crimen. Usos del relato policial en la narrativa argentina (1880-2000). Madrid: Iberoamericana/ Vervuert. 
Orecchia Havas, Teresa (2005): “La máscara y los héroes en Respiración Artificial", Revista Iberoamericana LXXI/213 (2005):1215-1229.

Piglia, Ricardo (1997). "La loca y el relato del crimen”. Cuentos morales. Buenos Aires: Planeta bolsillo: 89-98.

Piglia, Ricardo (2000). Formas breves. Barcelona: Anagrama.

Piglia, Ricardo [2001 (1986)]. Crúica y ficción. Barcelona: Anagrama.

Piglia, Ricardo (2005). El último lector. Barcelona: Anagrama.

Piglia, Ricardo (2010). Blanco nocturno. Barcelona: Anagrama.

Piglia, Ricardo [2011 (1991)]. "La ficción paranoica”. De Rosso, Ezequiel (coord.) Retóricas del crimen. Reflexiones latinoamericanas sobre el género policial. Jaén: Alcalá Grupo Editorial: 225-233/ Buenos Aires: Clarín. Suplemento Cultura y Nación.

Piglia, Ricardo [2012 (1997)]. Plata Quemada. Barcelona: Anagrama.

Piglia, Ricardo (2013). El camino de Ida. Barcelona: Anagrama.

Poe, Edgar Allan (2004). "Los crímenes de la calle Morgue". Obras Completas, Tomo I. Madrid: Aguilar: 402-428.

Rodríguez Pérsico, Adriana (2004). "Plata quemada o un mito para el policial argentino". Rodríguez Pérsico, Adriana (comp.). Ricardo Piglia: una poética sin límites. Pittsburgh: Instituto Internacional de Literatura Iberoamericana: 113-122.

Sarlo, Beatriz (1987): "Política, ideología y figuración literaria" en Ficción y política: la narrativa durante el proceso militar, Buenos Aires, Alianza Estudio.

Torres Perdigón, Andrea. "Reflexividad y narratividad en Ricardo Piglia: de Macedonio a Fitzgerald". Kamchatka. Revista de análisis cultural 1 (2013): 133-153.

Žižek, Slavoj (2000). Mirando al sesgo: Una introducción a Jacques Lacan a través de la cultura popular. Buenos Aires: Paidós: 89-117. 